\title{
Impact of variation in structure of condensed tannins from sainfoin (Onobrychis viciifolia) on in vitro ruminal methan production and fermentation characteristics
}

Article

Accepted Version

Hatew, B., Stringano, E., Mueller-Harvey, I., Hendriks, W. H., Hayot Carbonero, C., Smith, L. M. J. and Pellikaan, W. F. (2016) Impact of variation in structure of condensed tannins from sainfoin (Onobrychis viciifolia) on in vitro ruminal methan production and fermentation characteristics. Journal of Animal Physiology and Animal Nutrition, 100 (2). pp. 348-360. ISSN 1439-0396 doi: https://doi.org/10.1111/jpn.12336 Available at https://centaur.reading.ac.uk/39880/

It is advisable to refer to the publisher's version if you intend to cite from the work. See Guidance on citing.

To link to this article DOI: http://dx.doi.org/10.1111/jpn.12336

Publisher: Wiley

All outputs in CentAUR are protected by Intellectual Property Rights law, including copyright law. Copyright and IPR is retained by the creators or other copyright holders. Terms and conditions for use of this material are defined in 
the End User Agreement.

www.reading.ac.uk/centaur

\section{CentAUR}

Central Archive at the University of Reading

Reading's research outputs online 

viciifolia) on in vitro ruminal methane production and fermentation characteristics

B. Hatew ${ }^{1}$, E. Stringano ${ }^{2,}$, I. Mueller-Harvey ${ }^{2}$, W. H. Hendriks ${ }^{1,3}$, C. H. Carbonero ${ }^{4, \dagger}$, L. M.

$4 \quad$ J. Smith ${ }^{4}$, W. F. Pellikaan ${ }^{1}$

5

$6{ }^{1}$ Animal Nutrition Group, Wageningen University, P.O. Box 338, 6700 AH Wageningen, The

Netherlands

8
${ }^{2}$ Chemistry and Biochemistry Laboratory, Food Production and Quality Division, School of Agriculture, Policy and Development, University of Reading, 1 Earley Gate, P.O.Box 236, Reading RG6 6AT, UK ${ }^{3}$ Department of Farm Animal Health, Faculty of Veterinary Medicine, Utrecht University, P.O. Box 80163, 3508 TD Utrecht, The Netherlands ${ }^{4}$ National Institute of Agricultural Botany, Huntingdon Road, Cambridge CB3 OLE, UK

\section{Condensed tannins and in vitro methane production}

17 Correspondence:

Bayissa Hatew

9 P.O. Box 338, 6700 AH Wageningen, The Netherlands

Phone: +31317483282

1 E-mail: bayissa.chuko@,wur.nl

3 Present address:

4 *EBEWE Pharma Ges.m.b.H. Nfg.KG, Mondseestrasse 11, 4866 Unterach, Austria

25 University of Illinois at Urbana-Champaign, 1102 South Goodwin Avenue, Turner Hall, Urbana, IL 61801, USA 
Our study investigated the effects of condensed tannins (CT) on rumen in vitro methane $\left(\mathrm{CH}_{4}\right)$ production and fermentation characteristics by incubating lucerne in buffered rumen fluid in combination with different CT extracts at 0 (control), 40, 80 and $120 \mathrm{~g} \mathrm{CT} / \mathrm{kg} \mathrm{DM}$. Condensed tannins were extracted from 4 sainfoin accessions: Rees "A", CPI63763, Cotswold Common and CPI63767. Gas production (GP) was measured using a fully automated GP apparatus with $\mathrm{CH}_{4}$ measured at distinct time points. Condensed tannins differed substantially in terms of polymer size and varied from 13 (Rees "A") to 73 (CPI63767) mean degree of polymerization, but had relatively similar characteristics in terms of $\mathrm{CT}$ content, procyanidin:prodelphinidin (PC:PD) and cis:trans ratios. Compared to control, addition of CT from CPI63767 and CPI63763 at 80 and $120 \mathrm{~g} \mathrm{CT} / \mathrm{kg} \mathrm{DM}$ reduced $\mathrm{CH}_{4}$ by 43 and $65 \%$, and by 23 and $57 \%$, respectively, after $24 \mathrm{~h}$ incubation. Similarly, CT from Rees "A" and Cotswold Common reduced $\mathrm{CH}_{4}$ by 26 and $46 \%$, and by 28 and $46 \%$, respectively. Addition of increasing level of CT linearly reduced the maximum rates of GP and $\mathrm{CH}_{4}$ production, and the estimated in vitro organic matter digestibility. There was a negative linear and quadratic $(\mathrm{p}<0.01)$ relation between CT concentration and total volatile fatty acid (VFA) production. Inclusion of 80 and $120 \mathrm{~g} \mathrm{CT} / \mathrm{kg}$ DM reduced $(\mathrm{p}<0.001)$ branched-chain VFA production and acetate:propionate ratio and was lowest for CPI63767. A decrease in proteolytic activity as indirectly shown by a change in VFA composition favoring a shift towards propionate and reduction in branched-chain VFA production varied with type of CT, and was highest for CPI63767. In conclusion, these results suggest that tannin polymer size is an important factor affecting in vitro $\mathrm{CH}_{4}$ production which may be linked to the $\mathrm{CT}$ interaction with dietary substrate or microbial cells. Keywords: sainfoin, condensed tannin, polymer size, methane, in vitro 
Plants produce a vast array of different tannin types and concentrations (Khanbabaee and Van Ree, 2001; Mueller-Harvey, 2006; Huemmer and Schreier, 2008). For a long time tannins have been considered as an anti-nutritional factor in animal nutrition (Mueller-Harvey, 2006).

Whether tannins exert positive or negative effects appears to depend on the type and level of tannins in the plants (Barry and McNabb, 1999; Min et al., 2003), the amount ingested and the animal species involved (Frutos et al., 2004; Mueller-Harvey, 2006). It is of note, however, that only a few studies investigated their bioactivities and included a full tannin analysis. Most of these studies compared the procyanidin-rich Lotus corniculatus (birdsfoot trefoil) and the prodelphinidin-rich Lotus pedunculatus (big trefoil) tannin types (Molan et al., 2001; Min et al., 2003; Tavendale et al., 2005). However, condensed tannins (CT) vary considerably even within a single plant species (Koupai-Abyazani et al., 1993; Marais et al., 2000; Stringano et al., 2012). Studies are needed to test how this variation affects their biological activity in relation to ruminant nutrition, nitrogen and methane $\left(\mathrm{CH}_{4}\right)$ emission. Tannins of various origins have been shown to inhibit ruminal $\mathrm{CH}_{4}$ production either when fed to ruminants as tannin-containing forages (Woodward et al., 2001; Puchala et al., 2005) and as tannin extracts tested in vitro (Tavendale et al., 2005; Pellikaan et al., 2011b; Hassanat and Benchaar, 2013) or fed in vivo (Beauchemin et al., 2007; Animut et al., 2008; Bhatta et al., 2013). To date, this anti-methanogenic activity appears to be variable and could not be explained by simply grouping the tannins into hydrolysable or condensed tannin types (Bhatta et al., 2009; Pellikaan et al., 2011b), suggesting that specific chemical structural properties are responsible for their anti-methanogenic activity. However, to our knowledge, limited studies are available focusing on chemical structural composition of CT to elucidate which chemical property is most responsible in reducing ruminal $\mathrm{CH}_{4}$ production. 
77 The objective of this study was to investigate the structural variation of semi-purified condensed tannin extracts which had been obtained from 4 sainfoin accessions on rumen in vitro $\mathrm{CH}_{4}$ production and fermentation characteristics. We hypothesize that the mean degree of polymerization (i.e. polymer size) of the tannin molecule is the most important property determining its activity to inhibit in vitro $\mathrm{CH}_{4}$ production.

\section{Material and methods}

\section{Plant samples for preparation of condensed tannin extracts}

Four sainfoin accessions were selected from the EU 'HealthyHay' sainfoin germplasm collection based on their distinct differences in terms of CT structure (Stringano et al., 2012). The 4 accessions were: accession number 1165 (Rees “A”), 1123 (CPI63763), 1262 (Cotswold Common) and 1127 (CPI63767). The plants were grown at the National Institute of Agricultural Botany (NIAB; Cambridge, UK). Growing conditions and source of seeds were described previously (Carbonero et al., 2011). Sainfoin accessions were harvested when about $50 \%$ of stems showed open flowers on the lowest half of the flower stem. Plant material was packed in special bags (Nalgene low density polyethylene bags; $22.9 \times 45.7$ $\mathrm{cm}$ ), stored at $-20^{\circ} \mathrm{C}$, freeze-dried and then ground to pass an 8 -mm sieve using an impeller mill (Retsch GmbH, SM1, Haan, Germany), and subsequently ground to pass a 1-mm sieve (Retsch GmbH, ZM 100, Haan, Germany).

\section{Extraction of condensed tannins}

The CT extracts were prepared as described by Stringano et al. (2011). Briefly, $25 \mathrm{~g}$ of ground $(1 \mathrm{~mm})$ sainfoin sample was extracted once with acetone/water $(200 \mathrm{ml} ; 7: 3, \mathrm{v} / \mathrm{v})$ containing ascorbic acid (1 $\mathrm{g} / \mathrm{liter})$ for $40 \mathrm{~min}$. Chlorophyll was removed from the acetone/water solution by extracting twice with dichloromethane $(200 \mathrm{ml})$. Acetone was then removed on a rotary evaporator and the aqueous phase was concentrated in vacuum $(<40$ 
${ }^{\circ} \mathrm{C}$ ), and subsequently freeze-dried to yield CT extracts. The extracts were stored at $-20{ }^{\circ} \mathrm{C}$

102

103

104

105

106

107

108

109

$$
\mathrm{mDP}=\frac{\text { amount of extension and terminal flavanol units (mol) }}{\text { amount of terminal flavanol units (mol) }}
$$

$$
\mathrm{PC}: \mathrm{PD}=\frac{\text { percentage of } \mathrm{C}+\mathrm{EC} \text { units }}{\text { percentage of GC }+ \text { EGC units }}
$$

117

$$
\text { cis: trans }=\frac{\text { percentage of EC + EGC units }}{\text { percentage of C + GC units }}
$$

where C, catechin; EC, epicatechin; GC, gallocatechin; and EGC, epigallocatechin. 
Effects of $\mathrm{CT}$ on in vitro $\mathrm{CH}_{4}$ production and fermentation kinetics were examined using the tannin-free lucerne (Medicago sativa) as a substrate. Lucerne was harvested at 50\% flowering stage, freeze-dried and ground to pass a 1-mm sieve (Retsch GmbH, ZM 100, Haan, Germany).

The chemical composition of lucerne was: $\mathrm{OM}=800.0 \mathrm{~g} / \mathrm{kg} \mathrm{DM} ; \mathrm{CP}=188.0 \mathrm{~g} / \mathrm{kg} \mathrm{DM}$; NDF $=279.5 \mathrm{~g} / \mathrm{kg} \mathrm{DM}$ and $\mathrm{ADF}=211.2 \mathrm{~g} / \mathrm{kg} \mathrm{DM}$. Condensed tannins were prepared at 3 effective concentrations: 40, 80 and $120 \mathrm{~g} \mathrm{CT} / \mathrm{kg}$ of substrate DM. The extracts used in the present study differed in their CT contents and range from 5 to $11 \mathrm{~g} \mathrm{CT} / 100 \mathrm{~g}$ extract (Table 1). Therefore, the amount of $\mathrm{CT}$ extract required to achieve these 3 effective $\mathrm{CT}$ concentrations was weighed separately into Eppendorf vials and dissolved in $2 \mathrm{ml}$ of Millipore water (Milli-Q Academic, Amsterdam, The Netherlands) and added to the fermentation bottles at the onset of in vitro incubation. Condensed tannin extracts were dissolved in water to ensure its proper homogenization with the substrate.

\section{Rumen in vitro gas and methane production measurements}

Cumulative gas production (GP) was measured using a fully automated time related GP apparatus (Cone et al., 1996) and $\mathrm{CH}_{4}$ production at distinct time points as described by Pellikaan et al. (2011a). Approximately $250 \mathrm{mg}$ of substrate was weighed into $250 \mathrm{ml}$ fermentation bottles (Schott, Germany). Bottles were then randomly distributed within each GP unit, such that bottles with each substrate-CT extract treatment combination including the blanks were incubated in each GP unit. Rumen fluid was obtained from 3 ruminally fistulated lactating Holstein-Friesian dairy cows. Donor cows were fed a grass and maize silage mixture in the morning and afternoon and 7-8 $\mathrm{kg} / \mathrm{d}$ of concentrate according to their milk production. of Wageningen University (Wageningen, The Netherlands) and in accordance with the Dutch legislation on the use of experimental animals. 
144 Rumen fluid was collected prior to the morning feeding by suction method using a solid perforated plastic tube ( $85 \mathrm{~cm}$ long and $2.5 \mathrm{~cm}$ in diameter). Rumen fluid once collected was transferred into pre-warmed and carbon dioxide $\left(\mathrm{CO}_{2}\right)$ flushed thermos flasks, transported quickly to the laboratory, pooled and filtered through 2 layers of cheesecloth into a flask flushed with $\mathrm{CO}_{2}$. Filtered rumen fluid was mixed with the buffered mineral solution at 1:2 ratios (v/v) as described by Cone et al. (1996) with constant stirring and continuous flushing with $\mathrm{CO}_{2}$, while maintained in a water bath set to $39{ }^{\circ} \mathrm{C}$. Then, $30 \mathrm{ml}$ buffered rumen fluid mixture was subsequently dispensed in the fermentation bottle prewarmed to $39{ }^{\circ} \mathrm{C}$. Finally, CT solution was immediately added into the fermentation bottle and incubated in a water bath maintained at $39{ }^{\circ} \mathrm{C}$ and shaking at $40-50$ movements per minute. Control bottles containing substrate and buffered rumen fluid (i.e. without CT) were injected with $2 \mathrm{ml}$ of Millipore water.

The study was designed as a randomized complete block design with incubation run considered as a block. Each treatment and control were incubated in duplicate within a run and replicated in 2 runs on different days. Two bottles in each run were included as a blank (containing only buffered rumen fluid) and GP for each bottle was corrected for the blank values. The amount of gas, $\mathrm{CH}_{4}$ and VFA produced were adjusted to the total amount of organic matter $(\mathrm{OM})$ incubated and expressed per gram of incubated OM (substrate OM plus extra OM supplied with CT extracts).

Methane concentration in the headspace of the fermentation bottle was measured by gas chromatography (GC; GC8000Top, CE Instruments, Milan, Italy). To allow gas sampling from the headspace, the fermentation bottles were fitted with a side port sealed with a screw cap that is fitted with an air-tight septum (GRACE, XLB-11 Septa 7/16, Breda, The Netherlands) as illustrated by Pellikaan et al. (2011a). At distinct time points of incubation (0, $2,4,6,8,10,12,24,26,28,30,32,48,50,52,54$ and $72 \mathrm{~h}), 10 \mu 1$ aliquots of the bottles 
headspace gas were sampled through this opening using a gas tight syringe (Gastight ${ }^{\circledR} \# 1701$ Hamilton 1701N, $10 \mu$ l Syringe, Point Style 5, Bonaduz, Switzerland) and analyzed for $\mathrm{CH}_{4}$ concentration using GC. The GC was fitted with a flame ionization detector and stainless steel column (6 m long, $0.53 \mathrm{~mm}$ i.d., $25 \mu \mathrm{m}$ film thicknesses) packed with PoraPack Q 5080 mesh (GRACE, Breda, The Netherlands). The temperatures of the injector, column, and detector were maintained at $150{ }^{\circ} \mathrm{C}, 60{ }^{\circ} \mathrm{C}$ and $150{ }^{\circ} \mathrm{C}$, respectively. The carrier gas was nitrogen, and the pressure for nitrogen, hydrogen and air was set at 100, 50 and $100 \mathrm{kPa}$, respectively. The $\mathrm{CH}_{4}$ concentration was calculated by external calibration, using a certified gas mixture containing known composition of $\mathrm{CH}_{4}$ (Linde Gas Benelux, Schiedam, The Netherlands). Peak areas were determined by automatic integration system software (ChromCard data system Version 2.4, 2006, Rodano Milan, Italy) for GC.

Cumulative $\mathrm{CH}_{4}$ production was calculated following the procedure described by Pellikaan et al. (2011b; Eq. 4) by taking the sum of the increased amount of $\mathrm{CH}_{4}$ in the bottle headspace between 2 successive valve openings and the amount of $\mathrm{CH}_{4}$ vented from the bottle.

$$
\mathrm{M}=\sum_{i=1}^{n}\left\{\mathrm{~V}_{H S}\left(\mathrm{C}_{i+1}-\mathrm{C}_{i}\right)+\mathrm{G}_{i+1} \mathrm{C}_{i+1}\right\}
$$

where $\mathrm{M}$, cummulative $\mathrm{CH}_{4}$ production $(\mathrm{ml} / \mathrm{g}$ of incubated $\mathrm{OM}) ; \mathrm{V}_{\mathrm{HS}}$, the bottle headspace volume (ml); $\mathrm{C}_{\mathrm{i}}$ and $\mathrm{C}_{\mathrm{i}+1}, \mathrm{CH}_{4}$ concentration in the bottle headspace gas at $\mathrm{i}$ and $\mathrm{i}+1$ valve openings, respectively; $G_{i+1}$, the amount of gas (ml) vented at $i+1$ valve opening; and $n$, total number of valve openings.

\section{Curve fitting and calculations}

Cumulative gas and $\mathrm{CH}_{4}$ production curves were fitted iteratively with a triphasic and monophasic Michaelis-Menten equation (Groot et al., 1996; Eq. 5), respectively, using the nonlinear least squares regression procedure in SAS (SAS, 2010). 


$$
\mathrm{OMCV}=\sum_{i=1 \text { or } 3}^{n} \frac{\mathrm{A}_{i}}{1+\left(\mathrm{B}_{i} / \mathrm{t}\right)^{\mathrm{C}_{i}}}
$$

191 where $\mathrm{OMCV}$, gas or $\mathrm{CH}_{4}$ production $(\mathrm{ml} / \mathrm{g}$ of incubated $\mathrm{OM})$; $\mathrm{A}$, the asymptotic gas

192

193

194

195

196

197

198

199

200

201

202

203

204

205

206

207

208

209

210

production $(\mathrm{ml} / \mathrm{g}$ of incubated $\mathrm{OM}) ; \mathrm{B}$, time at which half of the asymptotic gas or $\mathrm{CH}_{4}$ production has been reached $\left(t_{1 / 2}, h\right) ; C$, the sharpness of the switching characteristics of the profile; and t, the time (h).

The maximum rate of gas or $\mathrm{CH}_{4}$ production ( $\mathrm{Rmax}, \mathrm{ml} / \mathrm{h}$ ) was calculated as described by Bauer et al. (2001; Eq. 6).

$$
\operatorname{Rmax}=\frac{\mathrm{A} \times \mathrm{B}^{\mathrm{C}} \times \mathrm{C} \times \mathrm{TRmax}^{(-\mathrm{C}-1)}}{\left(1+\mathrm{B}^{\mathrm{C}} \times \mathrm{TRmax}^{-\mathrm{C}}\right)^{2}}
$$

where $\mathrm{A}$, asymptote gas or $\mathrm{CH}_{4}$ production $(\mathrm{ml} / \mathrm{g}$ of incubated $\mathrm{OM}) ; \mathrm{B}$, time of incubation at which half of the asymptote gas or $\mathrm{CH}_{4}$ has been formed $\left(\mathrm{t}_{1 / 2}, \mathrm{~h}\right) ; \mathrm{C}$, the sharpness of the switching characteristic of the profile.

\section{In vitro organic matter digestibility}

The in vitro organic matter digestibility (IVOMD) was estimated according to the equation given by Menke and Steingass (1988; Eq. 7) based on 24 h gas production and nutrient composition of the substrate.

$$
\operatorname{IVOMD}(\%)=14.88+0.8893 \times \mathrm{GP}+0.0448 \times \mathrm{CP}+0.0651 \times \mathrm{A}
$$

where GP, 24 h net gas production $(\mathrm{ml} / 200 \mathrm{mg} \mathrm{DM})$; $\mathrm{CP}$, crude protein $(\%)$ and A, ash (\%) contents of the substrate.

\section{Analytical procedures}

Substrate sample was freeze dried, ground using a Wiley mill through a 1-mm sieve and analyzed for DM (ISO 6496, 1999), ash (ISO 5984, 2002) and N (ISO 5983, 2005). Crude protein content was calculated as: $\mathrm{CP}=6.25 \times \mathrm{N}$. Neutral detergent fiber and ADF were 
analyzed using an ANKOM2000 Fiber Analyzer (ANKOM Technology Corporation, NY,

212

213

214

215

216

217

218

219

220

221

222

223

224

225

226

227

228

229

230

231

232

233

234 USA).

The VFA sample $(750 \mu \mathrm{l})$ from each bottle after $72 \mathrm{~h}$ incubation was acidified with equal volume of orthophosphoric acid solution $(1: 1, \mathrm{v} / \mathrm{v})$ and stored at $-20{ }^{\circ} \mathrm{C}$ pending for further analysis. The VFA concentration was analyzed by GC as described by Taweel et al. (2005).

The VFA concentration in the medium was corrected for the VFA concentration of blank (i.e. rumen fluid plus buffer) and expressed as $\mathrm{mM} / \mathrm{g}$ of incubated OM.

\section{Statistical analysis}

All duplicate bottles per treatment within run were averaged prior to statistical analysis. Fermentation bottle was considered as an experimental unit. Data were subjected to analysis of variance based on a complete randomized design within a $4 \times 4$ factorial arrangement of treatments using the GLM procedure in SAS (SAS, 2010). For each CT type, the effects of $\mathrm{CT}$ concentration on gas, $\mathrm{CH}_{4}, \mathrm{VFA}$ and kinetic parameters were analysed for orthogonal polynomial contrasts. The model included treatment (CT level) as a fixed effect and block (run) as a random effect. Least square means for control and treatments are reported. Treatment effects were declared significant at $\mathrm{p} \leq 0.05$ and tendency at $0.05<\mathrm{p} \leq 0.10$.

\section{Results}

\section{Chemical composition of lucerne and chemical characteristics of condensed tannins}

The analyzed organic matter (OM) content of lucerne was somewhat lower than the expected. Since $\mathrm{GP}, \mathrm{CH}_{4}$ production and kinetic parameters were expressed per unit of $\mathrm{OM}$ for all treatments, the lower $\mathrm{OM}$ content of the lucerne does not affect differences between treatments. There was a large variation in CT average polymer sizes (mDP) among the $4 \mathrm{CT}$ types but much less variation in content, PC:PD and cis:trans ratios (Table 1). The mDP values varied from 13 to 73 (Rees "A" vs. CPI63767) and the CT contents from 5 to $11 \mathrm{~g}$ 
$235 \mathrm{CT} / 100$ g extract (CPI63767 vs. Rees "A"). The PC:PD ratios ranged from 23:77 to 29:71

236 (CPI63763 vs. Rees "A" and Cotswold Common) and cis:trans ratios from 68:32 to 79:21

237 (CPI63763 vs. Cotswold Common).

\section{Effect of condensed tannins on total gas and methane production}

239 Cumulative gas $(\mathrm{ml} / \mathrm{g}$ of incubated $\mathrm{OM})$ was reduced by the type and level of CT compared with the control (Table 2). A linear $(\mathrm{p}<0.001)$ reduction was observed with increasing CT level for all CT type after $72 \mathrm{~h}$. On average less gas was produced by inclusion of CT from CPI63767 and followed by Cotswold Common, Rees "A" and CPI63763 CT at 12, 24 and 72 h. Condensed tannins from CPI63767 when added at $\geq 80 \mathrm{~g} \mathrm{CT} / \mathrm{kg}$ of substrate DM consistently gave the lowest GP at 12, 24 and $72 \mathrm{~h}$ compared with the control and the other CT types. All types of CT when added at 80 and $120 \mathrm{~g} \mathrm{CT} / \mathrm{kg}$ of substrate DM have linearly decreased GP.

247

The effect of $\mathrm{CT}$ on $\mathrm{CH}_{4}$ production is presented in Table 3. Condensed tannins from CPI63767 were the most effective in reducing $\mathrm{CH}_{4}$ production followed by $\mathrm{CT}$ from CPI63763, Rees “A”, and Cotswold Common. Addition of CT at $40 \mathrm{~g} \mathrm{CT} / \mathrm{kg}$ of substrate DM, except CPI63767, did not affect $\mathrm{CH}_{4}$ production. Inclusion of CT from CPI63767 at 80 and $120 \mathrm{~g} \mathrm{CT} / \mathrm{kg}$ of substrate DM reduced $(\mathrm{p}<0.001) \mathrm{CH}_{4}$ by 43 and $65 \%$ compared with the control after $24 \mathrm{~h}$ incubation. Similarly, CT from CPI63763 reduced $(\mathrm{p}<0.001) \mathrm{CH}_{4}$ by 23 and $57 \%$ after $24 \mathrm{~h}$, whilst Rees "A" and Cotswold Common reduced $\mathrm{CH}_{4}$ by about 26 and $46 \%$, and 28 and $46 \%$, respectively. Inclusion of $\mathrm{CT}$ at $120 \mathrm{~g} \mathrm{CT} / \mathrm{kg}$ reduced $\mathrm{CH}_{4}$ production by $28 \%$ (Rees "A" and Cotswold Common) and 63\% (CPI63767) compared with the control after $72 \mathrm{~h}$ of incubation. Methane production expressed per unit IVOMD was $33.6 \mathrm{ml} / \mathrm{g}$ of OM degraded for control and 28.6, 20.4 and $12.5 \mathrm{ml} / \mathrm{g}$ of OM degraded for 40, 80 and $120 \mathrm{~g}$ (Table 3). 
More than $50 \%$ of total $\mathrm{CH}_{4}$ was produced in the first $12 \mathrm{~h}$ of incubation for the control

261

262

263

264

265

266

267

268

269

270

271

272

273

274

276

277

278

279

280

281

282

283

284 treatment, which was considerably more than when substrate was incubated with CT. The proportions of $\mathrm{CH}_{4}$ in total GP $(\mathrm{v} / \mathrm{v})$ showed a linear reduction $(\mathrm{p}<0.001)$ for CPI63767 (21.9\% to $12.1 \%)$ and CPI63763 (21.9\% to $14.7 \%)$, and a linear and quadratic effect for Cotswold Common and Rees "A" after $72 \mathrm{~h}$ incubation (Figure 2). A higher proportion of $\mathrm{CH}_{4}$ for Rees "A" $(22.8 \%)$ and Cotswold Common (24.3\%) were measured when CT was added at $40 \mathrm{~g} \mathrm{CT} / \mathrm{kg}$ compared with control (21.9\%) after $72 \mathrm{~h}$ of incubation (Table 3 ). The same trend was observed after $24 \mathrm{~h}$ of incubation. Depending on the type of $\mathrm{CT}, \mathrm{CH}_{4}$ produced as a proportion of total gas during $24 \mathrm{~h}$ incubation varied from $18.6 \%$ (control) to 13.2\% (CPI63767), 15.5\% (CPI63763), 15.5\% (Rees “A”) and 16.0\% (Cotswold Common) when CT was added at $80 \mathrm{~g} \mathrm{CT} / \mathrm{kg}$ substrate DM.

Table 4 presents a set of substrate fermentation kinetic parameters. Asymptotic GP for the first phase (A1; the first $3 \mathrm{~h}$ of incubation, which corresponds to fermentation of the soluble and rapidly fermentable fraction; Groot et al., 1996) decreased linearly $(\mathrm{p}<0.01)$ with increasing level of CT for all CT type. The asymptotic GP for the second phase (A2; 3-20 h of incubation, which corresponds to fermentation of the non-soluble fraction) only showed a linear $(\mathrm{p}<0.01)$ decrease for Cotswold Common and CPI63767. The asymptotic GP for the third phase (A3; 20-72 h of incubation, corresponds to microbial turn over) was both linearly $(\mathrm{p}<0.01)$ and quadratically $(\mathrm{p}<0.01)$ affected by CT from CPI63767. The rate of GP (Rmax1) decreased linearly ( $\mathrm{p}<0.05)$ with increasing level of CT, but was unaffected for CPI63763. The half-time of asymptotic GP in the first phase (B1) was longer for CT from Cotswold Common compared to control. In general, all CT types gave a longer B1 when added at 80 and $120 \mathrm{~g} \mathrm{CT} / \mathrm{kg}$ of substrate DM compared with the control. Similarly, increasing CT level from CPI63767 caused a higher reduction $(\mathrm{p}<0.01)$ of both Rmax1 and asymptotic $\mathrm{CH}_{4}$ production. For all $\mathrm{CT}$ types, the $\mathrm{B} 1$ of the asymptotic $\mathrm{CH}_{4}$ production was 
affected in a linear and quadratic manner $(\mathrm{p}<0.001)$. The asymptotic $\mathrm{CH}_{4}$ production was

286

287

288 also affected both linearly and quadratically, but only for CPI63767. On average, half of the asymptotic $\mathrm{CH}_{4}$ production was reached after $18.6 \mathrm{~h}$ (CPI63767), $18.8 \mathrm{~h}$ (CPI63763), $37.3 \mathrm{~h}$ (Rees "A") and $25.6 \mathrm{~h}$ for Cotswold Common as compared with $8.9 \mathrm{~h}$ for the control.

\section{Effects of condensed tannins on volatile fatty acids}

Condensed tannins had linear and quadratic effects on total and individual VFA production (Table 5). There was a negative linear and quadratic relation between CT level and VFA production for CPI63767, and linear effect for Cotswold Common. The proportion of propionate linearly increased at the expense of acetate, and butyrate decreased for all CT types and levels of inclusion compared to the control. The highest increase in propionate production was observed for CT from CPI63767 added at $120 \mathrm{~g} \mathrm{CT} / \mathrm{kg}$ of substrate DM. A similar increase in propionate was observed when CT was added at $80 \mathrm{~g} \mathrm{CT} / \mathrm{kg}$ of substrate DM. The ratio of acetate: propionate was the lowest for the same CT when added at 80 and $120 \mathrm{~g} \mathrm{CT} / \mathrm{kg}$ of substrate DM. The reduction in acetate:propionate ratio was $20 \%$ and $40 \%$ when CT was added at 80 and $120 \mathrm{~g} \mathrm{CT} / \mathrm{kg}$ of substrate DM, respectively, compared with only $3 \%$ reduction when CT was added at $40 \mathrm{~g} \mathrm{CT} / \mathrm{kg}$ of substrate DM. On average the decline (\% relative to control) in acetate:propionate ratio was 29\% (CPI63767), 22\% (CPI63763), 17\% (Rees “A”) and 16\% for Cotswold Common.

\section{Discussion}

\section{Chemical property of condensed tannins}

Condensed tannins (CT) from sainfoin (Onobrychis viciifolia) are rich in prodelphinidins and have a considerable spread of molecular weights, PC:PD ratios and tannin contents (Marais et al., 2000; Regos et al., 2009; Stringano et al., 2012). The 'HealthyHay' sainfoin germplasm collection provided a unique opportunity to obtain contrasting CT in terms of molecular 
weights but otherwise relatively similar characteristics in $\mathrm{CT}$ content, $\mathrm{PC}: \mathrm{PD}$ and cis:trans ratios (Table 1). Non-tannin components in acetone/water extracts consist of soluble carbohydrates (mainly sucrose), monomeric flavonoids and their glycosides and phenolic acids (Marais et al., 2000; Regos et al., 2009). These semi-purified CT extracts were used in the current study in order to assess the effects of different sainfoin CT types on rumen in vitro $\mathrm{CH}_{4}$ production and fermentation characteristics. Previous approaches have tested commercially available tannins, which were either water or alcohol extracts, and found that the potential to reduce $\mathrm{CH}_{4}$ production, or affect rumen fermentation and protein degradation varied with type and level of tannins (Getachew et al., 2008; Hassanat and Benchaar, 2013). Similarly, other studies, in which acetone/water extracts were added to in vitro systems, reported the effects of tannins on $\mathrm{CH}_{4}$ production and their role in animal feed vary depending on the type and concentrations of tannins (Pellikaan et al., 2011b; Sivakumaran et al., 2006; Beauchemin et al., 2007).

The CT used in the present study consisted mainly of prodelphinidins and a wide polymer size (mDP values) ranging from 13 to 73 (Table 1). However, the literature contains surprisingly contradictory information on the effect of tannin polymer size on antimethanogenic properties. Tavendale et al. (2005) found that CT polymers with a mDP value of 12.5 (DP range from 4 - 13) completely inhibited methane production, but CT oligomers with $\mathrm{mDP}$ values of 4.5 to 6.6 (DP range from $2-7$ ) had no inhibitory effect. In contrast, Field et al. (1989) found that autoxidized oligomers in particular had anti-methanogenic effects, whilst their autoxidized high molecular weight polymers showed no inhibiting effects. These seeming contradictions could arise from the fact that the autoxidized polymers from Field et al. (1989) are unlike the naturally occurring plant polymers studied by Tavendale et al. (2005). Another explanation could be that condensed tannins are highly specific in their anti-methanogenic properties just as reported previously for hydrolysable 
tannins (Pellikaan et al., 2011b) and for condensed tannins (Hassanat and Benchaar, 2013). It is also important to note that $\mathrm{mDP}$ values describe the 'average $\mathrm{CT}^{\text {' }}$ in a mixture of different tannin molecules and thus the CT distribution profiles will include tannins of different molecular weights (Stringano et al., 2011).

\section{Effect of CT on in vitro methane and VFA production}

339 The inclusion of CT from Rees "A" having the lowest polymer size $(\mathrm{mDP}=13)$ compared with CT from CPI63767 that has the highest polymer size $(\mathrm{mDP}=73)$ at the same concentration affected $\mathrm{CH}_{4}$ production differently (Table 3). We note that both $\mathrm{CT}$ types have relatively similar PC:PD ratios (29:71 and 25:75, respectively). The inclusion of CT from these two sources at $80 \mathrm{~g} \mathrm{CT} / \mathrm{kg}$ of substrate DM produced 59.3 and $46.6 \mathrm{ml} \mathrm{CH}_{4} / \mathrm{g}$ of incubated OM for CT from Rees “A” vs. CPI63767 after $72 \mathrm{~h}$ of incubation (Table 3). The same trend was observed when CT was added at $120 \mathrm{~g} \mathrm{CT} / \mathrm{kg}$ of substrate DM and incubated for 6, 12, and 24 h. Similarly, inclusion of CT from CPI63767 (mDP = 73; PC:PD = 25:75) compared to CT from CPI63763 $(\mathrm{mDP}=24 ; \mathrm{PC}: \mathrm{PD}=23: 73)$ at the same concentration, for instance, $80 \mathrm{~g} \mathrm{CT} / \mathrm{kg}$ of substrate $\mathrm{DM}$ reduced $\mathrm{CH}_{4}$ production to different extent. This suggests that the PC:PD ratio at least for the type of CT tested in the present study is not the main responsible factor explaining the differences observed in their potential of reducing in vitro $\mathrm{CH}_{4}$ production. In contrast, Molan et al. (2001) observed that CT extracts from prodelphinidin-rich big trefoil (Lotus pedunculatus) was more active in inhibiting the growth of proteolytic rumen bacteria than procyanidin-rich birdsfoot trefoil (Lotus corniculatus). The inconsistencies between studies could be due to difference in source of CT extracts (i.e. plant of origin) that might affect their activity to bind carbohydrates and proteins (McAllister et al., 2005).

The ratio of $\mathrm{CH}_{4}$ to total gas is an important indicator of the potential amount of $\mathrm{CH}_{4}$ produced per unit $\mathrm{OM}$ degraded. The proportion of $\mathrm{CH}_{4}$ in the total gas on average declined 
from $18.6 \%$ to $11.4 \%$; a reduction of $39 \%$ (control vs. $120 \mathrm{~g} \mathrm{CT} / \mathrm{kg}$ of substrate DM; Table 3). This is agreement with Hassanat and Benchaar (2013) who reported up to $40 \%$ reduction of $\mathrm{CH}_{4}$ production compared with control when substrate was incubated with condensed tannins at $\geq 100 \mathrm{~g} / \mathrm{kg}$ with minimum detrimental effects on efficiency of ruminal fermentation. Similarly, Waghorn et al. (2002) found that $\mathrm{CH}_{4}$ production was reduced by $31 \%$ when sheep were fed on Lotus pedunculatus (DMI $=935 \mathrm{~g} /$ day; CT content $=5.3 \mathrm{~g} / 100$ g DM) compared with Medicago sativa, a tannin-free legume. In the present study, addition of CT at $40 \mathrm{~g} \mathrm{CT} / \mathrm{kg}$ substrate DM from Rees "A" and Cotswold Common did not inhibit $\mathrm{CH}_{4}$ production (Table 3). However, at increasing $\mathrm{CT}$ levels $\mathrm{CH}_{4}$ production was inhibited. This is in consistence with a meta-analysis conducted by Jayanegara et al. (2011) who showed a significant negative correlation between $\mathrm{CT}$ concentration and in vitro $\mathrm{CH}_{4}$ production. Equally, McMahon et al. (1999) demonstrated that there is a linear suppression of in vitro $\mathrm{CH}_{4}$ production with an increasing proportion of sainfoin forage in lucerne. Regardless of the CT type, substrate incubated with $\geq 80 \mathrm{~g} \mathrm{CT} / \mathrm{kg}$ substrate DM was less degraded than the control as reflected by a lower in vitro OM digestibility (IVOMD; Table 2). In agreement with Kaplan (2011), who compared the in vitro ruminal degradability of 4 accessions of sainfoin hay (containing extractable CT varying from 49 to $100 \mathrm{~g} / \mathrm{kg} \mathrm{DM}$ ), and found that estimated IVOMD of sainfoin hay is negatively correlated with its CT content. In contrast, Theodoridou et al. (2011) found that sainfoin CT extracted from whole-plant, leaves and stems (CT content 13.6, 9.8 and $9.0 \mathrm{~g} / \mathrm{kg}$ DM for whole-plant, leaves and stems, respectively) inhibited in vitro $\mathrm{CH}_{4}$ production without altering its measured $\mathrm{OM}$ digestibility. The variations among studies could be due to: 1) in the study of Theodoridou et al. (2011) the IVOMD was measured, whereas in current study and that of Kaplan (2011) it was estimated from gas production and chemical composition of the substrate, or 2) lower CT content in the study of Theodoridou et al. (2011). 

63\% reduction in $\mathrm{CH}_{4}$ expressed per unit of IVOMD. This relationship between the reduction in $\mathrm{CH}_{4}$ production and $\mathrm{CT}$ concentration suggests that the effects of CT may be attributed for an important part to a negative effect on ruminal fiber degradation such as increased formation of tannin-cellulose complexes that are resistant to enzymatic digestion, or lessened substrate adhesion by fibrolytic microbes (Waghorn, 2008; McAllister et al., 2005). On the other hand, the linear and quadratic effect observed on VFA, or change in VFA composition (i.e. linear increase in propionate proportion and decrease in acetate:propionate ratio) with higher CT level (Table 5) suggest that a direct effect of $\mathrm{CT}$ on rumen methanogenesis is also prevailing. This effect could result from a reduction of available hydrogen, which is a substrate for methanogens (Bhatta et al., 2009; Smith et al., 2005; Tavendale et al., 2005). The reduction in hydrogen availability can be achieved when an alternative metabolic pathway such as propionate production disposes of the hydrogen produced during in vitro fermentation of substrate (López et al., 1999).

The increase in CT level except CT from Rees "A" and CPI63763 reduced total VFA production linearly. Hassanat and Benchaar (2013) also reported a decrease in in vitro VFA concentration when CT level was increased from 20 to $200 \mathrm{~g} / \mathrm{kg}$ of DM. However, in the current study, the addition of CT from CPI63767 resulted in less acetate, butyrate and lower acetate:propionate ratio when added at $80 \mathrm{~g} \mathrm{CT} / \mathrm{kg}$ of substrate DM compared with the control and other $\mathrm{CT}$ types. This is important in terms of $\mathrm{CH}_{4}$ reduction, since fermentation of $\mathrm{OM}$ to acetate and butyrate produces hydrogen, which is utilized in the rumen to produce $\mathrm{CH}_{4}$, while substrates that promote production of propionate in the rumen decreases $\mathrm{CH}_{4}$ production (Tavendale et al., 2005). This strong inverse relationship between propionate and

$407 \mathrm{CH}_{4}$ production can be predicted from knowledge of interactions among ruminal microbial 408 populations (Morgavi et al., 2010). The extent of linear and quadratic reduction in total VFA 
production, and the linear increase in propionate proportion and decrease in

410

411

412

413

414

415

416

417 acetate:propionate ratio for different $\mathrm{CT}$ types with increasing $\mathrm{CT}$ levels indicates an antimethanogenic effect, in which the effect depends on the type of CT. Earlier it was reported the activities of CT on ruminal VFA production and composition vary depending on CT level and source (Beauchemin et al., 2007; Bueno et al., 2008; Hassanat and Benchaar, 2013).

For better assessment of the overall environmental impact of different CT types and levels in ruminant diets other greenhouse gas emissions such as $\mathrm{N}_{2} \mathrm{O}$ will also need to be considered in addition to enteric $\mathrm{CH}_{4}$ production. This is important because $\mathrm{CT}$ can also affect protein degradation (Martínez et al., 2006); but they can also increase the utilization of branchedchain VFA (iso-acids) for microbial protein synthesis. In fact, both effects are likely, as dietary CT have been reported to be associated with reduction of protein degradation in the rumen (Hassanat and Benchaar, 2013; Getachew et al., 2008; Waghorn and Shelton, 1997). The iso-acids VFA arise almost exlusively from the oxidative deamination of amino acids. In addition, these branched-chain VFA production also decreased linearly as CT level increased and becomes negative when CT were added at higher concentration (Table 5), indicating that there was net uptake of these branched-chain VFA as the result of protection of proteins by CT from rumen deamination. This effect was more pronounced with CT from CPI63767 and added at $80 \mathrm{~g} \mathrm{CT} / \mathrm{kg}$ of substrate or higher level. In agreement with our results, Makkar et al. (1988) also reported that the protein precipitation capacity of CT depends on the type of tannins and the degree of polymerization. This can have a positive effect by increasing the amount of rumen-escape protein as well as causing a higher flow of microbial proteins to the intestine and hence improve $\mathrm{N}$ utilization when $\mathrm{CT}$ are supplied in ruminant diets.

Moreover, the effect observed on protein fermentation as indirectly evidenced by a change in VFA composition favoring a shift towards propionate and reduction of branched-chain VFA (Table 5) is consistent with a recent in vivo study on sainfoin of Aufrére et al. (2013), who 
reported that sainfoin $\mathrm{CT}$ generated rumen-escape protein and enabled better utilization in the small intestine and higher $\mathrm{N}$ retention as the dietary proportion of sainfoin was increased.

\section{Conclusion}

437 Condensed tannins obtained from sainfoin accessions are promising for reducing rumen $\mathrm{CH}_{4}$ 438 production. There were significant differences in the anti-methanogenic activity among the 439 CT extracts, which could be attributed to differences in tannin polymer size (mDP values). 列 6 7 These size differences may have affected the ability of tannins to interact with dietary fiber and proteins or microbial cells. A decrease in proteolytic activity as indirectly shown by a change in VFA composition favoring a shift towards propionate and reduction in branchedchain VFA production which can be seen as a potential advantage in terms of improving $\mathrm{N}$ utilization by ruminants. This study generated preliminary evidence that tannin polymer size is an important factor as far as $\mathrm{CH}_{4}$ and VFA production are concerned. Next to knowledge about the actual degree of polymerization, its proportional distributions could be of interest. A study with a wider range in $\mathrm{CT}$ structure (PC:PD and cis:trans ratios) is recommended to unambiguously assess the impact of CT structures on activity without detrimental effects on fiber degradation.

\section{Acknowledgements}

This study was supported by the European Commission (MRTN-CT-2006-035805) 'HealthyHay' project. The technical assistance of Mr. Michel Breuer in VFA analysis is highly acknowledged. The authors would like to thank Mr. Jeerasak Chobtang for his assistance during the experiment and Mr. Ronald Wormgoor with the rumen fluid sampling. 


\section{References}

459

460

461

462

463

464

465

466

467

468

469

470

471

472

473

474

475

476

477

478

479

480

Animut, G.; Puchala, R.; Goetsch, A. L.; Patra, A. K.; Sahlu, T.; Varel, V. H.; Wells, J., 2008: Methane emission by goats consuming diets with different levels of condensed tannins from lespedeza. Animal Feed Science and Technology 144, 212-227.

Aufrére, J.; Dudilieu, M.; Andueza, D.; Poncet, C.; Baumont, R., 2013: Mixing sainfoin and lucerne to improve the feed value of legumes fed to sheep by the effect of condensed tannins. Animal 7, 82-92.

Barry, T. N.; McNabb, W. C., 1999: The implications of condensed tannins on the nutritive value of temperate forages fed to ruminants. British Journal of Nutrition 81, 263-272.

Bauer, E.; Williams, B. A.; Voigt, C.; Mosenthin, R.; Verstegen, M. W. A., 2001: In vitro fermentation of various carbohydrate-rich feed ingredients combined with chyme from pigs. Archives of Animal Nutrition 64, 394-411.

Beauchemin, K. A.; McGinn, S. M.; Martínez, T. F.; McAllister, T. A., 2007: Use of condensed tannin extract from quebracho trees to reduce methane emissions from cattle. Journal of Animal Science 85, 1990-1996.

Bhatta, R.; Enishi, O.; Yabumoto, Y.; Nonaka, I.; Takusari, N.; Higuchi, K.; Tajima, K.; Takenaka, A.; Kurihara, M., 2013: Methane reduction and energy partitioning in goats fed two concentrations of tannin from Mimosa spp. Journal of Agricultural Science 151, $119-128$

Bhatta, R.; Uyeno, Y.; Tajima, K.; Takenaka, A.; Yabumoto, Y.; Nonaka, I.; Enishi, O.; Kurihara, M., 2009: Difference in the nature of tannins on in vitro ruminal methane and volatile fatty acid production and on methanogenic archaea and protozoa populations. Journal of Dairy Science 92, 5512-5522. 
Bueno, I. C. S.; Dorinha, M. S. S.; Vitti, L. H.; Abdalla, A. L., 2008: A new approach for in vitro bioassay to measure tannin biological effects based on a gas production technique. Animal Feed Science and Technology 141, 153-170.

Carbonero, C. H.; Mueller-Harvey, I.; Brown, T. A.; Smith, L., 2011: Sainfoin (Onobrychis viciifolia): A beneficial forage legume. Plant Genetic Resources Characterization and Utilization 9, 70-85.

Cone, J. W.; Van Gelder, A. H.; Visscher, G. J. W.; Oudshoorn, L., 1996: Influence of rumen fluid and substrate concentration on fermentation kinetics measured with a fully automated time related gas production apparatus. Animal Feed Science and Technology 61, 113-128.

Field, J. A.; Kortekaas, S.; Lettinga, G., 1989: The tannin theory of methanogenic toxicity. Biological Wastes 29, 241-262.

Frutos, P.; Hervas, G.; Giraldez, F. J.; Mantecon, A. R., 2004: Tannins and ruminant nutrition. Spanish Journal of Agricultural Research 2, 191-202.

Gea, A.; Stringano, E.; Brown, R. H.; Mueller-Harvey, I., 2011: In situ analysis and structural elucidation of sainfoin (Onobrychis viciifolia) tannins for high-throughput germplasm screening. Journal of Agricultural and Food Chemistry 59, 495-503.

Getachew, G.; Pittroff, W ; Putnam, D. H.; Dandekar, A; Goyal, S ; DePeters, E. J., 2008: The influence of addition of gallic acid, tannic acid, or quebracho tannins to alfalfa hay on in vitro rumen fermentation and microbial protein synthesis. Animal Feed Science and Technology 140, 444-461.

Groot, J. C. J.; Cone, J. W.; Williams, B. A.; Debersaques, F. M. A.; Lantinga, E. A., 1996: Multiphasic analysis of gas production kinetics for in vitro fermentation of ruminant feeds. Animal Feed Science and Technology 64, 77-89. 
504 Hassanat, F.; Benchaar, C., 2013: Assessment of the effect of condensed (acacia and 505 quebracho) and hydrolysable (chestnut and valonea) tannins on rumen fermentation and 506 methane production in vitro. Journal of the Science of Food and Agriculture 93, 332-339.

507 Huemmer, W.; Schreier, P., 2008: Analysis of proanthocyanidins. Molecular Nutrition and 508 Food Research 52, 1381-1398.

ISO 6496, 1999: Animal feeding stuffs. Determination of moisture and other volatile matter content. International Organization for Standardization, Geneva, Switzerland.

ISO 5984, 2002: Animal feeding stuffs. Determination of crude ash. International Organization for Standardization, Geneva, Switzerland.

ISO 5983, 2005: Animal feeding stuffs. Determination of nitrogen content and calculation of crude protein content - Kjeldahl method. International Organization for Standardization, Geneva, Switzerland.

Jayanegara, A.; Leiber, F; Kreuzer, M., 2011: Meta-analysis of the relationship between dietary tannin level and methane formation in ruminants from in vivo and in vitro

Kaplan, M., 2011: Determination of potential nutritive value of sainfoin (Onobrychis sativa) hays harvested at flowering stage. Journal of Animal Veterinary Advances 10, 2028-2031.

Khanbabaee, K.; Van Ree, T., 2001: Tannins: Classification and definition. Natural Products Reports 18, 641-649.

523 Koupai-Abyazani, M. R.; Muir, A. D.; Bohm, B. A.; Towers, G. H. N.; Gruber, M. Y., 1993: $113-117$.

López, S.; Valdés, C.; Newbold, C. J.; Wallace, R. J., 1999: Influence of sodium fumarate addition on rumen fermentation in vitro. British Journal of Nutrition 81, 59-64. 
Makkar, H. P. S.; Dawra, R. K.; Singh, B., 1988: Changes in tannin content, polymerization and protein precipitation capacity in Oak (Quercus incana) leaves with maturity. Journal of the Science of Food and Agriculture 44, 301-307.

McAllister, T. A.; Martinez, T.; Bae, H. D.; Muir, A. D.; Yanke, L. J.; Gones, G. A., 2005: Characterization of condensed tannins purified from legume forages: Chromophore production, protein precipitation and inhibitory effects on cellulose digestion. Journal of Chemical Ecology 31, 2049-2068.

Marais, J. P. J.; Mueller-Harvey, I.; Brandt, E. V.; Ferreira, D., 2000: Polyphenols, condensed tannins, and other natural products in Onobrychis viciifolia (sainfoin). Journal of Agricultural and Food Chemistry 48, 3440-3447.

Martínez, T. F.; McAllister, T. A.; Wang, Y.; Reuter, T., 2006: Effects of tannic acid and quebracho tannins on in vitro ruminal fermentation of wheat and corn grain. Journal of the Science of Food and Agriculture 86, 1244-1256.

McMahon, L. R.; Majak, W.; McAllister, T. A.; Hall, J. W.; Jones, G. A.; Poppi, J. D.; Cheng, K. J., 1999: Effect of sainfoin on in vitro digestion of fresh alfalfa and bloat in steers. Canadian Journal of Animal Science 79, 203-212.

Menke, K. H.; Steingass, H., 1988: Estimation of the energetic feed value obtained from chemical analysis and in vitro gas production using rumen fluid. Animal Research and Development, 28, 7-55.

Min, B. R.; Barry, T. N.; Attwood, G. T.; McNabb, W. C., 2003: The effect of condensed tannins on the nutrition and health of ruminants fed fresh temperate forages. Animal Feed Science and Technology 106, 3-19.

Molan, A. L.; Attwood, G. T.; Min B. R.; McNabb, W. C., 2001: The effect of condensed tannins from Lotus pedunculatus and Lotus corniculatus on the growth of proteolytic 
rumen bacteria in vitro and their possible mode of action. Canadian Journal of Microbiology 47, 626-633.

Morgavi, D. P.; Forano, E.; Martin, C; Newbold, C. J., 2010: Microbial ecosystem and methanogenesis in ruminants. Animal 4, 1024-1036.

Mueller-Harvey, I., 2006: Unravelling the conundrum of tannins in animal nutrition and health. Journal of the Science of Food and Agriculture 86, 2010-2037.

Pellikaan, W. F.; Hendriks, W. H.; Uwimana, G.; Bongers, D. J. G. M.; Becker, P. M.; Cone J. W., 2011a: A novel method to determine simultaneously methane production during in vitro gas production using fully automated equipment. Animal Feed Science and Technology 168,196-205.

562

Pellikaan, W. F.; Stringano, E.; Leenaars, J.; Bongers, D. J. G. M.; van Laar-van Schuppen, S.; Plant J.; Mueller-Harvey, I., 2011b: Evaluating effects of tannins on extent and rate of in vitro gas and $\mathrm{CH}_{4}$ production using an automated pressure evaluation system (APES). Animal Feed Science and Technology 166-67, 377-390.

567

Puchala, R.; Min, B. R.; Goetsch, A. L.; Sahlu, T., 2005: The effect of a condensed tannincontaining forage on methane emission by goats. Journal of Animal Science 83, 182-186.

Regos, I.; Urbanella, A.; Treutter, D., 2009: Idenficiation and quantification of phenolic compounds from the forage legume sainfoin (Onobrychis viciifolia). Journal of Agricultural and Food Chemistry 57, 5843-5852.

SAS., 2010: Statistical Analysis Software. SAS/STAT 9.3 User's Guide. SAS Inst. Inc., Cary, NC.

Sivakumaran, S.; Rumball, W.; Lane, G. A.; Fraser, K.; Foo, L. Y.; Yu, M.; Meagher, L. P., 2006: Variation of proanthocyanidins in Lotus species. Journal of Chemical Ecology 32, 1797-1816. 
576 Smith, A. H.; Zoetendal, E. G.; Mackie, R. I., 2005: Bacterial mechanisms to overcome 577 inhibitory effects of dietary tannins. Journal of Microbial Ecology 50, 197-205.

578 Stringano, E.; Carbonero, C. H.; Smith, L.; Mueller-Harvey, I., 2012: Proanthocyanidin 579 diversity in the EU 'HealthyHay' sainfoin (Onobrychis viciifolia) germplasm collection. Phytochemistry 77, 197-208.

Stringano, E.; Cramer, R.; Hayes, W.; Smith, C.; Gibson, T.; Mueller-Harvey, I., 2011: 
600 Waghorn, G. C.; Shelton, I. D., 1997: Effect of condensed tannins in Lotus corniculatus on 601 the nutritive value of pasture for sheep. Journal of Agricultural Science 128, 365-372.

602 Waghorn, G. C.; Tavendale, M. H.; Woodfield D. R., 2002: Methanogenesis from forages fed 603 to sheep. Proceedings of New Zealand Grassland Association 64, 159-165.

604 Woodward, S. L.; Waghorn, G. C.; Ulyatt, M. J.; Lassey, K. R., 2001: Early indications that 605 feeding Lotus will reduce methane emissions from ruminants. Proceedings of New 606 Zealand Society of Animal Production 61, 23-26.

607

608

609

610

611

612

613

614

615

616

617

618

619

620

621

622

623

624 
625 Figure 1. Structural features of condensed tannins.

626 Figure 2. The effect of type and concentration of $\mathrm{CT}$ in the proportion $\mathrm{CH}_{4}$ production 627 (expressed as percent of total gas) compared with the control after $72 \mathrm{~h}$ incubation $(* * \mathrm{p}<$ $6280.01 ; * * * \mathrm{p}<0.001)$.

629

630

631

632

633

634

635

636

637

638

639

640

641

642

643

644

645

646

647

648

649 
Table 1 Condensed tannins (CT) content, mean degree of polymerization, $\mathrm{PC}: \mathrm{PD}$ and cis:trans ratios in aqueous acetone extracts obtained from 4 sainfoin accessions $^{*}$

\begin{tabular}{lclll}
\hline CT type & $\begin{array}{c}\text { CT content } \\
(\mathrm{g} / 100 \text { g extract })\end{array}$ & $\mathrm{mDP}^{\dagger}$ & $\mathrm{PC}: \mathrm{PD}^{\ddagger}$ & cis:trans $^{\S}$ \\
\hline Rees "A" & $11(2.2)$ & $13(2.3)$ & $29: 71(1.4)$ & $78: 22(4.4)$ \\
CPI63763 & $7(1.9)$ & $24(6.7)$ & $23: 77(2.6)$ & $68: 32(3.9)$ \\
Cotswold Common & $10(1.5)$ & $31(1.6)$ & $29: 71(0.7)$ & $79: 21(1.7)$ \\
CPI63767 & $5(0.9)$ & $73(3.0)$ & $25: 75(2.0)$ & $74: 26(2.0)$ \\
\hline
\end{tabular}

651

652

653

654

655

656

657

658

659

660

661

662

663

664

665

666

667

668 
Table 2 Effect of type and concentration of sainfoin CT on in vitro gas production $(\mathrm{ml} / \mathrm{g}$ of incubated $\mathrm{OM}$ ) and in vitro organic matter digestibility of lucerne

\begin{tabular}{|c|c|c|c|c|c|c|}
\hline \multirow{2}{*}{ CT type } & \multirow{2}{*}{$\begin{array}{l}\text { CT concentration } \\
(\mathrm{g} / \mathrm{kg} \text { of substrate } \mathrm{DM})\end{array}$} & \multicolumn{4}{|c|}{ Time of post incubation (h) } & \multirow[b]{2}{*}{ IVOMD* } \\
\hline & & 6 & 12 & 24 & 72 & \\
\hline \multirow[t]{7}{*}{ Rees "A" } & 0 & 216.9 & 257.3 & 290.9 & 309.8 & 62.1 \\
\hline & 40 & 188.0 & 226.6 & 257.1 & 271.1 & 54.7 \\
\hline & 80 & 171.4 & 227.9 & 258.6 & 279.6 & 54.9 \\
\hline & 120 & 149.5 & 205.4 & 228.0 & 243.5 & 50.4 \\
\hline & $\mathrm{SEM}^{\dagger}$ & 3.92 & 3.91 & 5.10 & 5.48 & 0.76 \\
\hline & Linear & $<0.001$ & $<0.001$ & $<0.001$ & $<0.001$ & $<0.001$ \\
\hline & Quadratic & 0.400 & 0.321 & 0.763 & 0.823 & 0.055 \\
\hline \multirow[t]{7}{*}{ CPI63763 } & 0 & 216.9 & 257.3 & 290.9 & 309.8 & 62.1 \\
\hline & 40 & 199.0 & 251.2 & 290.0 & 308.5 & 59.6 \\
\hline & 80 & 185.9 & 237.0 & 268.1 & 290.5 & 56.4 \\
\hline & 120 & 159.4 & 205.4 & 227.1 & 239.6 & 50.3 \\
\hline & SEM & 4.24 & 4.34 & 4.52 & 5.99 & 0.67 \\
\hline & Linear & $<0.001$ & $<0.001$ & $<0.001$ & $<0.001$ & $<0.001$ \\
\hline & Quadratic & 0.335 & 0.085 & 0.165 & 0.212 & 0.091 \\
\hline \multirow{7}{*}{$\begin{array}{l}\text { Cotswold } \\
\text { Common }\end{array}$} & 0 & 216.9 & 257.3 & 290.9 & 309.8 & 62.1 \\
\hline & 40 & 186.9 & 237.1 & 268.6 & 284.1 & 56.2 \\
\hline & 80 & 162.4 & 217.8 & 242.0 & 258.0 & 52.3 \\
\hline & 120 & 145.1 & 202.3 & 227.6 & 242.0 & 50.2 \\
\hline & SEM & 4.58 & 3.12 & 3.25 & 4.51 & 0.49 \\
\hline & Linear & $<0.001$ & $<0.001$ & $<0.001$ & $<0.001$ & $<0.001$ \\
\hline & Quadratic & 0.201 & 0.475 & 0.257 & 0.315 & 0.102 \\
\hline \multirow[t]{7}{*}{ CPI63767 } & 0 & 216.9 & 257.3 & 290.9 & 309.8 & 62.1 \\
\hline & 40 & 187.6 & 239.9 & 273.9 & 292.3 & 57.3 \\
\hline & 80 & 160.7 & 206.1 & 231.9 & 251.6 & 51.1 \\
\hline & 120 & 144.6 & 181.8 & 199.6 & 206.5 & 46.3 \\
\hline & SEM & 3.50 & 3.69 & 4.20 & 5.76 & 0.62 \\
\hline & Linear & $<0.001$ & $<0.001$ & $<0.001$ & $<0.001$ & $<0.001$ \\
\hline & Quadratic & 0.387 & 0.374 & 0.099 & 0.638 & 0.959 \\
\hline
\end{tabular}

672 SEM $=$ standard error of the means. 
Table 3 Effect of type and concentration of sainfoin CT on in vitro methane production $(\mathrm{ml} / \mathrm{g}$ of incubated $\mathrm{OM}$ ), proportion of methane in total gas and methane produced per unit estimated OM degraded ( $\mathrm{ml} / \mathrm{g}$ of degraded OM)

\begin{tabular}{|c|c|c|c|c|c|c|c|}
\hline \multirow{2}{*}{ CT type } & \multirow{2}{*}{$\begin{array}{l}\text { CT concentration } \\
(\mathrm{g} / \mathrm{kg} \text { of substrate } \mathrm{DM})\end{array}$} & \multicolumn{4}{|c|}{ Time of post incubation (h) } & \multirow{2}{*}{$\begin{array}{l}\mathrm{CH}_{4} \text { per } \\
\text { total gas }\end{array}$} & \multirow{2}{*}{$\begin{array}{l}\mathrm{CH}_{4} \text { per } \\
\text { IVOMD }\end{array}$} \\
\hline & & 6 & 12 & 24 & 72 & & \\
\hline \multirow[t]{7}{*}{ Rees "A" } & 0 & 26.7 & 40.7 & 54.0 & 68.0 & 18.6 & 33.6 \\
\hline & 40 & 22.1 & 35.6 & 50.9 & 61.8 & 20.0 & 28.1 \\
\hline & 80 & 18.0 & 28.1 & 40.2 & 59.3 & 15.5 & 22.0 \\
\hline & 120 & 12.5 & 19.3 & 28.9 & 49.0 & 12.7 & 14.6 \\
\hline & $\mathrm{SEM}^{\dagger}$ & 1.25 & 1.25 & 0.66 & 3.99 & 0.46 & 0.39 \\
\hline & Linear & $<0.001$ & $<0.001$ & $<0.001$ & 0.012 & $<0.001$ & $<0.001$ \\
\hline & Quadratic & 0.737 & 0.196 & 0.321 & 0.622 & 0.002 & 0.055 \\
\hline \multirow[t]{7}{*}{ CPI63763 } & 0 & 26.7 & 40.7 & 54.0 & 68.0 & 18.6 & 33.6 \\
\hline & 40 & 22.6 & 36.4 & 51.2 & 66.8 & 17.6 & 30.5 \\
\hline & 80 & 17.4 & 29.4 & 41.5 & 56.5 & 15.5 & 23.5 \\
\hline & 120 & 10.6 & 16.6 & 23.3 & 35.2 & 10.3 & 11.7 \\
\hline & SEM & 1.65 & 2.04 & 2.42 & 4.14 & 0.66 & 1.40 \\
\hline & Linear & $<0.001$ & $<0.001$ & $<0.001$ & $<0.001$ & $<0.001$ & 0.001 \\
\hline & Quadratic & 0.437 & 0.070 & 0.073 & 0.442 & 0.199 & 0.104 \\
\hline Cotswold & 0 & 26.7 & 40.7 & 54.0 & 68.0 & 18.6 & 33.6 \\
\hline \multirow[t]{6}{*}{ Common } & 40 & 22.6 & 37.6 & 52.1 & 69.0 & 19.4 & 29.3 \\
\hline & 80 & 12.9 & 30.9 & 38.8 & 53.3 & 16.1 & 20.3 \\
\hline & 120 & 11.5 & 19.1 & 29.4 & 49.1 & 12.9 & 14.8 \\
\hline & SEM & 1.59 & 1.67 & 0.76 & 3.35 & 0.41 & 0.32 \\
\hline & Linear & $<0.001$ & $<0.001$ & $<0.001$ & 0.002 & $<0.001$ & $<0.001$ \\
\hline & Quadratic & 0.432 & 0.340 & 0.468 & 0.088 & 0.001 & 0.125 \\
\hline \multirow[t]{7}{*}{ CPI63767 } & 0 & 26.7 & 40.7 & 54.0 & 68.0 & 18.6 & 33.6 \\
\hline & 40 & 20.1 & 32.9 & 46.3 & 61.0 & 16.9 & 26.5 \\
\hline & 80 & 13.8 & 21.5 & 30.7 & 46.6 & 13.3 & 15.7 \\
\hline & 120 & 9.1 & 13.9 & 18.9 & 24.9 & 9.5 & 8.7 \\
\hline & SEM & 1.30 & 1.70 & 1.71 & 3.49 & 0.56 & 0.81 \\
\hline & Linear & $<0.001$ & $<0.001$ & $<0.001$ & $<0.001$ & $<0.001$ & $<0.001$ \\
\hline & Quadratic & 0.493 & 0.962 & 0.261 & 0.074 & 0.086 & 0.924 \\
\hline
\end{tabular}

674 Proportion of $\mathrm{CH}_{4}$ in total gas (\%) estimated based on $24 \mathrm{~h}$ incubation.

675 'SEM $=$ standard error of the means. 
Table 4 Effect of type and concentration of sainfoin CT on in vitro methane and gas production kinetics parameters of lucerne

\begin{tabular}{|c|c|c|c|c|c|c|c|c|c|c|c|c|c|}
\hline \multirow[t]{2}{*}{ CT type } & \multirow{2}{*}{$\begin{array}{l}\text { CT concentration } \\
\text { (g/kg of substrate DM) }\end{array}$} & \multicolumn{3}{|c|}{$\begin{array}{l}\text { Methane kinetics } \\
\text { parameters }\end{array}$} & \multicolumn{9}{|c|}{ Gas production kinetics parameters ${ }^{*}$} \\
\hline & & A1 & $\mathrm{B} 1$ & $\mathrm{Rmax} 1$ & A1 & $\mathrm{A} 2$ & A3 & B1 & $\mathrm{B} 2$ & B3 & Rmax 1 & Rmax2 & Rmax3 \\
\hline \multirow[t]{7}{*}{ Rees "A" } & 0 & 67.4 & 8.9 & 4.9 & 157.3 & 123.9 & 25.5 & 2.0 & 5.1 & 7.4 & 100.8 & 19.7 & 2.4 \\
\hline & 40 & 71.1 & 13.9 & 4.0 & 129.5 & 106.2 & 23.6 & 1.6 & 4.1 & 21.9 & 86.2 & 16.4 & 2.0 \\
\hline & 80 & 84.2 & 27.2 & 2.9 & 122.4 & 141.4 & 31.0 & 3.2 & 4.9 & 10.3 & 66.1 & 15.2 & 1.5 \\
\hline & 120 & 87.1 & 70.6 & 1.3 & 98.1 & 98.4 & 18.8 & 1.0 & 5.4 & 11.3 & 50.5 & 13.1 & 1.3 \\
\hline & $\mathrm{SEM}^{\dagger}$ & 6.61 & 9.77 & 1.00 & 7.76 & 12.41 & 3.18 & 1.40 & 2.05 & 6.39 & 14.36 & 1.33 & 0.27 \\
\hline & Linear & 0.095 & 0.011 & 0.010 & 0.006 & 0.366 & 0.295 & 0.236 & 0.623 & 0.918 & 0.021 & 0.003 & 0.007 \\
\hline & Quadratic & 0.890 & 0.113 & 0.536 & 0.833 & 0.060 & 0.042 & 0.025 & 0.925 & 0.032 & 0.973 & 0.633 & 0.812 \\
\hline \multirow[t]{7}{*}{ CPI63763 } & 0 & 67.4 & 8.9 & 4.9 & 157.3 & 123.9 & 25.5 & 2.0 & 5.1 & 7.4 & 100.8 & 19.7 & 2.4 \\
\hline & 40 & 85.3 & 13.7 & 3.6 & 142.4 & 139.3 & 31.0 & 1.0 & 4.8 & 19.5 & 68.9 & 16.3 & 2.2 \\
\hline & 80 & 67.6 & 14.9 & 3.0 & 133.5 & 136.7 & 30.9 & 1.3 & 4.5 & 16.0 & 73.2 & 14.2 & 1.3 \\
\hline & 120 & 52.8 & 27.8 & 1.7 & 105.4 & 123.7 & 18.1 & 2.3 & 4.0 & 10.3 & 53.3 & 18.9 & 3.5 \\
\hline & SEM & 5.09 & 3.59 & 0.96 & 6.22 & 2.37 & 3.06 & 0.69 & 0.72 & 2.19 & 15.76 & 1.76 & 0.64 \\
\hline & Linear & 0.045 & 0.028 & 0.032 & 0.004 & 0.103 & 0.120 & 0.172 & 0.208 & 0.439 & 0.067 & 0.554 & 0.376 \\
\hline & Quadratic & 0.063 & 0.265 & 0.236 & 0.240 & 0.004 & 0.052 & 0.088 & 0.045 & 0.013 & 0.668 & 0.040 & 0.088 \\
\hline Cotswold & 0 & 67.4 & 8.9 & 4.9 & 157.3 & 123.9 & 25.5 & 2.0 & 5.1 & 7.4 & 100.8 & 19.7 & 2.4 \\
\hline \multirow[t]{5}{*}{ Common } & 40 & 78.7 & 13.2 & 3.4 & 136.9 & 135.5 & 25.4 & 2.9 & 3.3 & 10.3 & 82.8 & 16.4 & 1.5 \\
\hline & 80 & 53.7 & 17.0 & 2.5 & 96.1 & 110.2 & 21.3 & 3.3 & 3.7 & 11.0 & 63.4 & 13.9 & 1.8 \\
\hline & 120 & 74.6 & 46.6 & 1.5 & 90.2 & 98.5 & 19.7 & 3.1 & 4.3 & 9.3 & 47.1 & 12.7 & 1.1 \\
\hline & SEM & 4.34 & 2.07 & 1.20 & 7.20 & 4.70 & 6.09 & 1.91 & 2.49 & 6.46 & 17.19 & 1.44 & 0.28 \\
\hline & Linear & 0.592 & $<0.001$ & 0.001 & 0.002 & 0.005 & 0.391 & 0.715 & 0.921 & 0.502 & 0.036 & 0.003 & 0.010 \\
\hline
\end{tabular}




\begin{tabular}{|c|c|c|c|c|c|c|c|c|c|c|c|c|c|c|}
\hline & & Quadratic & 0.023 & 0.003 & 0.365 & 0.367 & 0.012 & 0.997 & 0.016 & 0.794 & 0.248 & 0.916 & 0.499 & 0.765 \\
\hline \multirow[t]{7}{*}{ CPI63767 } & 0 & & 67.4 & 8.9 & 4.9 & 157.3 & 123.9 & 25.5 & 2.0 & 5.1 & 7.4 & 100.8 & 19.7 & 2.4 \\
\hline & 40 & & 75.3 & 13.7 & 3.7 & 140.1 & 140.8 & 30.1 & 2.8 & 4.8 & 15.9 & 78.1 & 14.9 & 2.0 \\
\hline & 80 & & 72.0 & 29.7 & 2.9 & 113.2 & 120.0 & 26.7 & 2.2 & 6.3 & 6.5 & 75.9 & 27.4 & 6.2 \\
\hline & 120 & & 30.7 & 13.1 & 1.2 & 93.5 & 108.5 & 11.1 & 2.3 & 3.8 & 9.9 & 25.6 & 13.2 & 0.9 \\
\hline & & SEM & 4.85 & 1.56 & 1.06 & 5.12 & 1.35 & 1.90 & 1.36 & 0.73 & 3.76 & 17.65 & 1.34 & 1.16 \\
\hline & & Linear & 0.005 & 0.023 & $<0.001$ & 0.001 & $<0.001$ & 0.004 & 0.353 & 0.283 & 0.923 & 0.015 & 0.250 & 0.859 \\
\hline & & Quadratic & 0.009 & 0.003 & 0.460 & 0.962 & 0.002 & 0.008 & 0.132 & 0.097 & 0.022 & 0.490 & 0.004 & $<0.001$ \\
\hline
\end{tabular}

$680 \quad{ }^{*} \mathrm{~A}=$ asymptotic gas or $\mathrm{CH}_{4}$ production (A1, A2, A3 indicates different phases; $\mathrm{ml} / \mathrm{g}$ of incubated $\mathrm{OM}$ ); $\mathrm{B}=$ half-time of asymptotic gas or $\mathrm{CH} 4$

681 production (B1, B2, B3 indicates different phases; h); Rmax = rate of maximum gas or $\mathrm{CH}_{4} \operatorname{production}\left(\mathrm{Rmax}_{1}, \mathrm{Rmax}_{2}, \mathrm{Rmax}_{3}\right.$ indicates

682 different phases; $\mathrm{ml} / \mathrm{h}$ ).

683 'SEM $=$ standard error of the means.

684

685

686

687

688

689

690

691

692

693

694

695

696

697

698 
Table 5 Effect of type and concentration of sainfoin CT on total VFA production and molar proportions of individual VFA

\begin{tabular}{|c|c|c|c|c|c|c|c|c|}
\hline \multirow{2}{*}{ CT type } & \multirow{2}{*}{$\begin{array}{l}\text { CT concentration } \\
\text { (g/kg substrate DM) }\end{array}$} & \multirow{2}{*}{$\begin{array}{l}\text { Total VFA } \\
(\mathrm{mM} / \mathrm{g} \mathrm{OM})\end{array}$} & \multicolumn{5}{|c|}{ Individual VFA $(\mathrm{mol} / 100 \mathrm{~mol})^{*}$} & \multirow[b]{2}{*}{ Ace:Pro } \\
\hline & & & Ace & Pro & But & Val & BCVFA & \\
\hline \multirow[t]{7}{*}{ Rees "A" } & 0 & 5.29 & 65.53 & 23.33 & 7.00 & 1.30 & 2.83 & 2.83 \\
\hline & 40 & 5.37 & 67.10 & 25.35 & 4.75 & 1.23 & 1.63 & 2.65 \\
\hline & 80 & 4.94 & 67.55 & 27.43 & 3.45 & 1.13 & 0.50 & 2.50 \\
\hline & 120 & 5.13 & 63.38 & 33.33 & 2.30 & 1.15 & -0.15 & 1.93 \\
\hline & $\mathrm{SEM}^{\dagger}$ & 0.112 & 0.719 & 0.939 & 0.155 & 0.037 & 0.098 & 0.119 \\
\hline & Linear & 0.100 & 0.087 & $<0.001$ & $<0.001$ & 0.006 & $<0.001$ & $<0.001$ \\
\hline & Quadratic & 0.609 & 0.002 & 0.161 & 0.154 & 0.199 & 0.106 & 0.120 \\
\hline \multirow[t]{7}{*}{ CPI63763 } & 0 & 5.29 & 65.53 & 23.33 & 7.00 & 1.30 & 2.83 & 2.83 \\
\hline & 40 & 5.34 & 67.63 & 24.68 & 4.30 & 1.78 & 1.65 & 2.75 \\
\hline & 80 & 5.72 & 65.90 & 29.23 & 2.43 & 2.03 & 0.45 & 2.25 \\
\hline & 120 & 5.24 & 60.00 & 37.48 & 1.28 & 2.05 & -0.80 & 1.60 \\
\hline & SEM & 0.134 & 0.644 & 0.690 & 0.076 & 0.042 & 0.072 & 0.080 \\
\hline & Linear & 0.689 & $<0.001$ & $<0.001$ & $<0.001$ & $<0.001$ & $<0.001$ & $<0.001$ \\
\hline & Quadratic & 0.069 & $<0.001$ & 0.201 & 0.312 & $<0.001$ & 0.611 & 0.064 \\
\hline \multirow{7}{*}{$\begin{array}{l}\text { Cotswold } \\
\text { Common }\end{array}$} & 0 & 5.29 & 65.53 & 23.33 & 7.00 & 1.30 & 2.83 & 2.83 \\
\hline & 40 & 5.17 & 68.53 & 23.73 & 4.90 & 1.15 & 1.70 & 2.90 \\
\hline & 80 & 4.98 & 66.13 & 29.40 & 3.18 & 1.00 & 0.30 & 2.28 \\
\hline & 120 & 4.96 & 63.83 & 33.08 & 2.33 & 0.98 & -0.20 & 1.95 \\
\hline & SEM & 0.093 & 0.674 & 0.833 & 0.124 & 0.028 & 0.075 & 0.118 \\
\hline & Linear & 0.014 & 0.029 & $<0.001$ & $<0.001$ & $<0.001$ & $<0.001$ & $<0.001$ \\
\hline & Quadratic & 0.600 & 0.002 & 0.373 & 0.181 & 0.045 & 0.213 & 0.035 \\
\hline \multirow[t]{7}{*}{ CPI63767 } & 0 & 5.29 & 65.53 & 23.33 & 7.00 & 1.30 & 2.83 & 2.83 \\
\hline & 40 & 5.56 & 67.80 & 25.73 & 3.70 & 1.45 & 1.35 & 2.65 \\
\hline & 80 & 5.29 & 63.98 & 32.08 & 2.18 & 1.50 & 0.25 & 2.00 \\
\hline & 120 & 4.52 & 56.68 & 42.15 & 1.00 & 1.43 & -1.28 & 1.35 \\
\hline & SEM & 0.117 & 0.528 & 0.685 & 0.123 & 0.028 & 0.081 & 0.097 \\
\hline & Linear & $<0.001$ & $<0.001$ & $<0.001$ & $<0.001$ & 0.005 & $<0.001$ & $<0.001$ \\
\hline & Quadratic & 0.001 & $<0.001$ & 0.321 & 0.172 & 0.002 & 0.763 & 0.180 \\
\hline
\end{tabular}

699 "Ace = acetate; Pro = propionate; But = butyrate; Val = valerate; BCVFA = branched-chain

700 VFA (iso-butyrate + iso-valerate).

701 'SEM $=$ standard error of the means.

702 


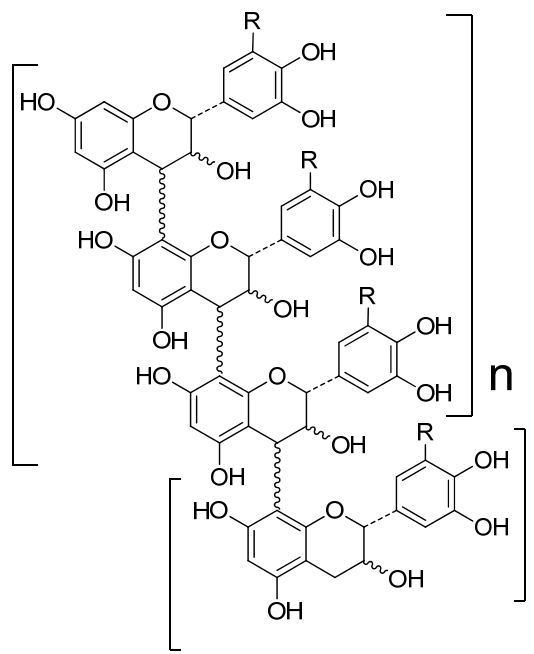

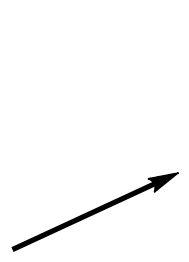

HS

$\mathrm{n} x$

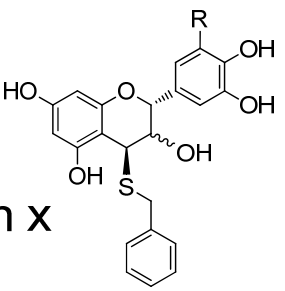
Extension units (i.e. upper units)

$\mathrm{R}=\mathrm{H}:-(+)$-catechin-BM

......'1 (-)-epicatechin-BM

$\mathrm{R}=\mathrm{OH}:-(+)$-gallocatechin-BM

........" (-)-epigallocatechin-BM

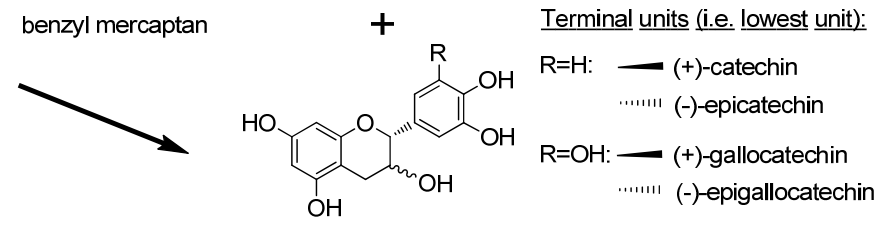

705

Figure 1.

706

707

708

709

710

711

712

713

714

715

716

717

718

719

720

721

722 


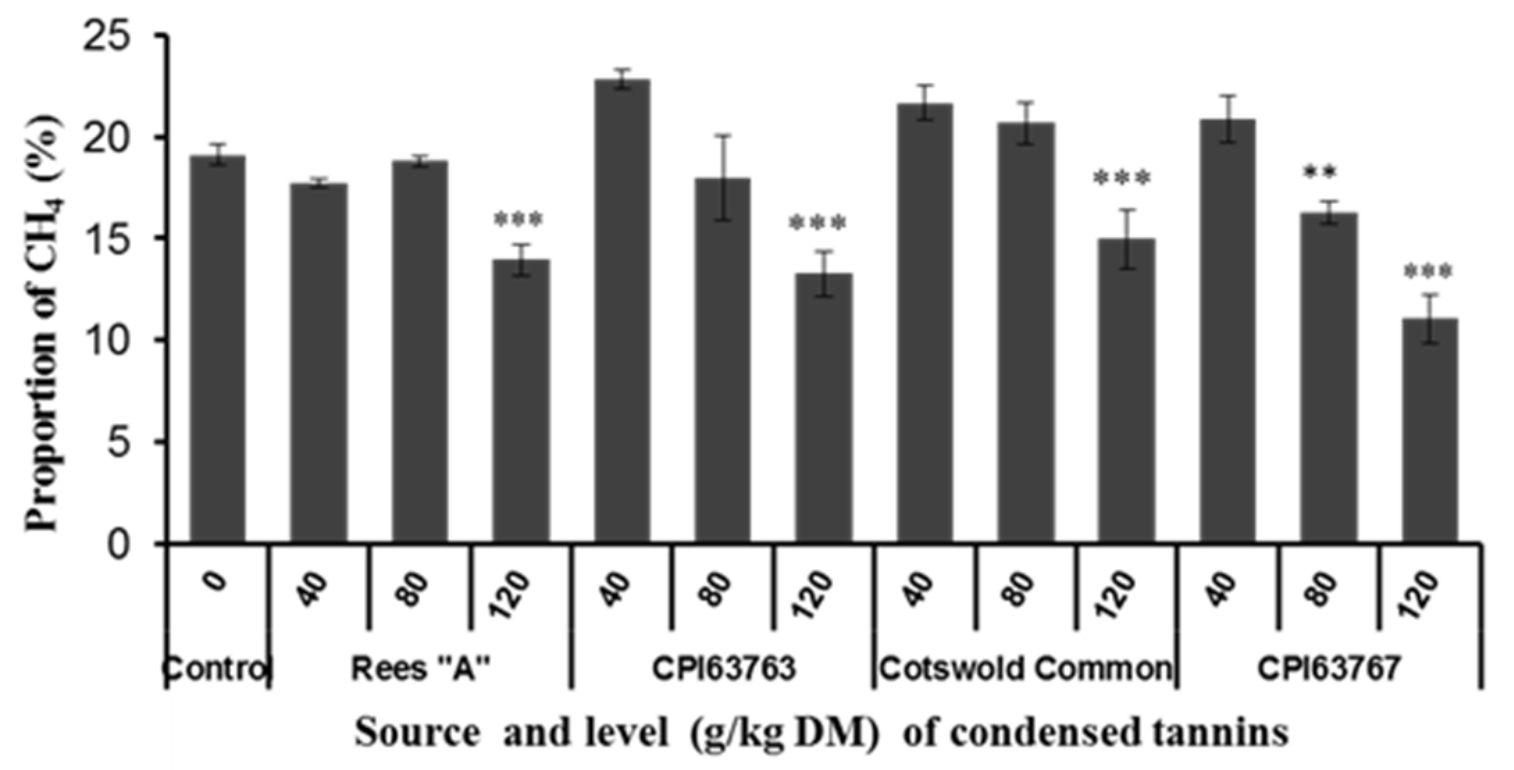

723

724

Figure 2.

725

726

727

728

729

730

731

732

733

734

735

736

737

738 